\title{
Rethinking Methods to Curb Gender Discrimination in Church Leadership: The Case of Pentecostal Churches in Zimbabwe
}

\author{
Charity Musvota \\ https://orcid.org/0000-0002-1623-9193 \\ Tshwane University of Technology \\ charitymusvota@gmail.com
}

\section{Abstract}

The patriarchal structure that has pervaded and replicated itself, not only in the society but also in the church, has raised questions on how the church can get out of this quagmire. Many proposals have been propounded from different angles on the topic in question, and this paper seeks to add a voice to the discourse. The paper assesses the effectiveness of methods used in Pentecostal churches in Zimbabwe to address and curb gender discrimination. The research concludes that although Pentecostal churches in Zimbabwe have made concerted efforts to curb gender inequality in the church, the methods used have not been able to effectively mitigate the gender imbalance that previously existed. The research that directed this article was grounded on the Pentecostal hermeneutics theory as well as the African feminist theory. This article acknowledges the valuable inputs of the late Mary-Anne Elizabeth PlaatjiesVan Huffel, who dedicated her work to the cause of gender inclusiveness and the eradication of social injustices. Her vast contribution, as an academic and minister in the Uniting Reformed Church in Southern Africa (URCSA), reverberated throughout the theological and academic milieu in southern Africa, and indeed in the world. The researcher used a qualitative approach as well as interviews and participant observation to gather data, together with secondary data from published books and journals. The study recommends educating people about the importance of gender balance and the inclusion of gender, a message of inclusion and new practices and traditions, and the creation of a structure for change. Roadmaps and paths for change are to be built. The research will be beneficial to political, social, economic and religious systems to alter the discrepancies in gender discrimination that are propelled by beliefs, a mind-set and culture proponents that seem to derail the value and contribution of women.

\section{UNISA $\cong$}


Keywords: patriarchy; feminism; gender discrimination; gender imbalance; mitigation; curb

\section{Introduction}

The message of the Bible is that the kingdom of God is open to everyone, regardless of gender, ethnicity, social class or age. However, the church, being in a patriarchal culture, does not always reflect this. Although Pentecostals in Zimbabwe are advocating for gender inclusiveness, it is quite evident that the methods they have used thus far have failed to effectively curtail gender imbalance. The gender disparities that exist show that the leadership crisis, which is evident in civil and civic societies in Zimbabwe, is also found in the church. Hence, there is a need to rethink the methods used to curb gender discrimination in church leadership.

It must be emphasised that the matter of gender inequality is widely experienced, and is not unique to the Pentecostal churches in Zimbabwe. Mary-Anne Elizabeth PlaatjiesVan Huffel did extensive research on this challenge, especially as experienced within the Uniting Reformed Church in Southern Africa (URCSA). She states: "The author contends that the issue of gender sensitivity is an existential issue. Gender is a social, cultural and religious construct. The concept 'gender' describes the differences between women and men which are based on socially defined ideas and beliefs of what it means to be a woman and a man ... Gender refers to the social roles allocated respectively to women and to men in particular societies and at particular times ... that is, the values and roles society assigns them" (Plaatjies-Van Huffel 2019, 3).

\section{Theoretical Framework}

In this article, two theories are used, namely the African feminist theory and the Pentecostal hermeneutics theory. The African feminist theory provides a lens and can be used to address the question of how to curb gender discrimination in church leadership, with reference to Pentecostal churches in Zimbabwe. It advocates for the emancipation of women and is against sexism and gender discrimination. Thus, the events and experiences of women in the Pentecostal churches can be articulated. The African feminist theory was used to analyse gender balance/imbalance in Pentecostal leadership.

According to Anderson (2012), the feminist theory argues that the philosophy of religion can hardly ignore the questions of gender ideology when its very subject matter, religion, is riddled with misogyny and andro-centrism. Anderson (2012) further points out that, historically, gender bias in religion has been neither accidental nor superficial. Jantzen (1999) views gender imbalance on an equal par to burying a continent; for women comprise half the human race. Hence, the feminist theory, within the patriarchal structures of religion has compromised gender balance, as can be seen by the way a gender hierarchy has been well-articulated culturally, reinforced and consolidated in various institutions. 
African feminists are of the view that men, like their female counterparts, are equally oppressed and therefore gender equality should advocate for the emancipation of both males and females. This is quite relevant to the present research study, which seeks to better the methods used in the church to promote gender equality in church leadership. Msafropolitan (2012) notes that African feminism agrees that African patriarchal traditions make distinctions between male and female in ways that disadvantage the female, but it does not seek to abandon tradition. The goal is to enable tradition to adapt to the times so that rather than stagnate, it can enrich society, as customs and culture should do. Thus, in this article, the African feminist theory is explored, since it is relevant in the sense that it seeks to develop both male and female emancipation. Its emphasis is on gender balance, making it more relevant for this study.

Apart from the feminist theory, Pentecostal hermeneutics was also used in the research study. Anderson (2012) defines Pentecostal hermeneutics as a method of interpreting scripture that addresses the same core issues common to evangelical hermeneutics, but in which the constituent elements and various emphases are unique. Furthermore, according to Togarasei (2016), Pentecostals uniquely combine biblical historical narratives with their personal experience, theological biases, church history and other fundamentals in their hermeneutics. Pentecostal hermeneutics has helped to show the Pentecostal beliefs, values and attitudes that have contributed to discrimination against women in leadership. Pentecostal hermeneutics has also helped in showing how Pentecostals have modelled their leadership structure on patriarchal forms. Thus, in this article, the African feminist theory and Pentecostal hermeneutics became relevant in articulating the compromise of gender balance in Pentecostal churches in Zimbabwe.

\section{History and Birth of Pentecostalism in Zimbabwe}

According to Anderson (2012), William Joseph Seymour is believed to have originated Pentecostalism when he held the Azusa Street revival of 1906 in Los Angeles, California. It is reported that, after the Azusa Street revival, Pentecostal Christianity spread and reached 50 different nations within a decade of its existence (Anderson 2012). To most of the Pentecostal missionaries, the gospel was supposed to be preached to all four corners of the world and as a result, Africa was not going to be left out in the growth of the Pentecostal movement-hence the continent received its share of missionaries. The notable early Pentecostal missionaries who came to South Africa were Henry and Anna Turney, Charles Chawner, Jacob Lehmann, John G. Lake and others (Machingura 2018). A number of Pentecostal churches were first registered as Assemblies of God in Africa, although they were later known for schisms (Anderson 2012), something that has characterised modern Pentecostal Christianity. Ironically, the same schisms also contributed to the growth of Pentecostal Christianity in Africa (Machingura2018).

According to Machingura (2018), Nicholas Bhengu is one of the greatest schismatic Pentecostal leaders whose "Back to God Crusades" brought many Africans into Pentecostalism. Although African pastors and evangelists played a major role in the 
growth of the Pentecostal movement in Africa, they were not noted in the history books, except for Nicholas Bhengu, whose contribution to the South African Assemblies of God could not be ignored (Anderson 2012). Schisms occurred within the Apostolic Faith Mission (AFM) in South Africa, resulting in a number of denominations, which included the Zion Christian Church, led by Engenas Lekganyane. Paul Kruger, a revered missionary in the history of the AFM in Zimbabwe, moved from South Africa to Zimbabwe and established the AFM (Anderson 2012).

According to Kgatle (2019), the historical development of women's role in the AFM in South Africa can be traced back to 1910, when the white Executive Council (EC) allowed black women to be preachers and in that capacity, they could be ordained. He further noted that this was at a local assembly level, not at a high leadership position. Women were only used as missionary workers and could not take influential positions in the Executive Council (Kgatle 2019). Kgatle (2019) further points out that the women who tried to rise were dismissed, for example the AFM saw it fit to dismiss Maria Fraser mainly because her prophecies were not proper. She had prophesied that the church was spiritually dry and that sins were on the rise. It would have been better for the AFM to look for other ways of disciplining her, rather than just to dismiss her. Hence, Kgatle (2019) has concluded that it shows that the AFM was biased towards women leadership because there were male counterparts who had committed greater sins than Maria Fraser, but who were not dismissed.

Women played an important role in the early Pentecostalism and the challenges that they faced as unpronounced recipients were overcome, since they were allowed to participate in the activities that they were previously kept from. Women such as Agnes Ozman, Florence Crawford, and Aimee Semple McPherson founded new denominations and many served as pastors and co-pastors (Bhatasara 2017). Anderson (2012) notes that although women were incorporated into the system, most had to copastor in order to gain support from society. He further points out that Maria Woodworth-Etter founded her own church, but needed to collaborate with John Alexander Dowie, so that she would find recognition from other churches.

It is noted that when Paul Kruger established the AFM in Zimbabwe, it became the mother of Zimbabwean Pentecostalism. Kruger's converts in Zimbabwe, such as Chiumbu, Masembe and the Gwanzura brothers, were instrumental in putting Pentecostalism on the map in Zimbabwe (Machingura 2011). Togarasei (2010) pointed out that within the AFM there was a group of young Pentecostal zealots (Joseph Choto, Raphael Kupara, Lazarus Mamvura, James Muhwati, Priscilla Ngoma, Caleb Ngorima and Abel Sande) who formed a prayer band and choir around the charismatic evangelist, Ezekiel Guti. This group was later expelled from the AFM in 1959, following doctrinal misunderstandings (Togarasei 2010). The group then formed their own organisation which was later called the Zimbabwe Assemblies of God Africa (ZAOGA). According to Anderson (2012), ZAOGA became one of the most successful AFM splinter churches. ZAOGA became a daughter of the AFM and schisms from ZAOGA saw the 
birth of AFM grandchildren (Machingura 2011). From the AFM, a number of churches have been established, including the United Family International Church (UFIC) of Emmanuel Makandiwa, the Heartfelt International Ministries of Tavonga Vutabwashe, and many others. In this article, the selection of Pentecostal churches to be discussed is limited to the AFM, ZAOGA, UFIC, Heartfelt International Ministries, Faith World Ministries, and Full Gospel of God. This brand of Pentecostal churches paints the characteristics of Pentecostalism in Zimbabwe.

\section{History of Women in Zimbabwean Pentecostal Churches}

The history of women in Zimbabwean Pentecostal churches has been described by Rutoro $(2012,1)$ as follows: "Imagine yourself trying to accomplish a goal, but an invisible force prevents you from reaching it." "Women in Zimbabwe try their best to climb the social ladder but the compensation of their work has remained a target which, though visible has been unattainable" (Rutoro2012,1). According to Kwaramba (2018), the silencing and side-lining of women are found in most spheres and disciplines, and the church and other secular institutions are not exceptions. Even in the home, male children in Zimbabwe have always been treated differently from female children; they have had greater access to the public sphere, including education, in comparison to female children who have always been confined to the domestic sphere where they are conditioned to become mothers and wives. This domestication of women from a tender age ushered the girl child into an unequal reality that then spilled into the church.

Although the original intention of Pentecostalism (as it originated from America) was to break the discrimination barrier, in Zimbabwe, when Pentecostalism was established, this intention was problematised by traditional culture. This culture was that women in the church, like in all other spheres of society, occupied marginal roles and were thus treated as valueless, subservient and voiceless (Nadar 2004). Durham (2016) asserts that although women in Pentecostal churches were the backbone of the church financially, spiritually and socially, they were sadly not recognised in decisions that mattered most in the church. A good example is ZAOGA; in 1960 women like Mbuya Rembo financed and supported the church in Bindura through the teaching of what the ZAOGAns term "talents" (teaching people how to be business minded and use their abilities to empower themselves financially) (Guti 2012). The teaching of talents was, therefore, both a way of economically empowering women and at the same time it emphasised supporting the church with the profits these women made. Regardless of all the support that women rendered to the church, there was not even a single woman who was appointed to a decision-making position or in the top executive.

Moreover, in ZAOGA and the AFM, women have constituted and still constitute the majority of the members since the 1960s, but men are the ones who have had exclusive access to power. This trend has continued for years and it was only after 2000 that women started to emerge as leaders, although this was limited to "women-to-women" ministries (Kwaramba 2018, 62). Women to reckon with include Florence Kanyati, Petunia Chiriseri and Chipo Bhasera. Initially, from the 1960s to the 1990s in the AFM 
and ZAOGA, women married to church founders were not recognised as "pastors" but were viewed simply as "Mai Mufundisi," meaning pastor's wife (Kwaramba 2018, 62). This meant that the pastor is the "man" and the woman is the pastor's wife who caters for the needs of her husband. Thus, the shift that transpired in 2000 in ZAOGA, whereby women could be ordained as pastors in their own right, was of significance to the issue of gender balance in the church. However, still titles like "apostle" and "bishop" remained unattainable to women, even though their husbands were bishops or apostles. As for the AFM, by 2019 it had ordained 2400 pastors but only 300 were female. In 2013, ZAOGA made history by ordaining Dr Eunor Guti as archbishop of the church, making her the first woman to hold such a position in Zimbabwe. She also became the second female archbishop in Africa, following Archbishop Margaret Benson-Idahosa, wife of the late archbishop of the Church of God Mission International of Nigeria.

\title{
Characteristics of Pentecostalism In Zimbabwe
}

According to Mapuranga (2013), spiritual gifts distinguish Pentecostal churches from other churches. The birth of Pentecostal movements in Zimbabwe was evidenced by followers of Christ exhibiting the gifts of the Holy Spirit, often referred to as supernatural gifts (Sande 2016). The book of Acts explains how spiritual gifts originated from the history of Pentecost. These spiritual gifts include healing power, prophesying, and speaking in and the interpretation of tongues.

\begin{abstract}
When the day of Pentecost had come, they were all together in one place. And suddenly from heaven, there came a sound like the rush of a violent wind and it filled the entire house where they were sitting. Divided tongues as of fire, appeared among them and a tongue rested on each of them. All of them were filled with the Holy Spirit and began to speak in other languages as the spirit gave them ability. (Acts 2:1-4 New International Version [NIV] $)^{1}$
\end{abstract}

The gift of speaking in tongues is the supernatural ability of the believer enabled by the Lord to begin to speak in another language not learnt. The physical evidence of the Holy Spirit baptism is the speaking in tongues. Hence, Pentecostals in Zimbabwe believe that the utterance of tongues is the initial evidence of the baptism of the Holy Spirit.

Apart from speaking in tongues, Pentecostalism in Zimbabwe emphasises the personal relationship with God. According to Rosinah Mmannana Gabaitse (2015), the priority should be on a personal relationship that the believers have with their God, rather than just speaking in tongues during church services. She goes on to say that it is great when a believer speaks in tongues, and his or her relationship with God is equally intact, and life is fulfilled.

To add to the above, power over demons and Satan is another distinguishing feature of Pentecostals in Zimbabwe. According to Laden (2012), the Pentecostals in Zimbabwe

1 In this article, all quotations from scripture are from the Bible, New International Version. https://www.thenivbible.com/. 
emphasise that the name of Jesus has power over demons. Amanze (2015) further explains that it is important to note that it is not just ministers who have authority over demons in the name of Jesus, but all believers. Therefore, believers need to know that they have the authority to cast out demons.

Furthermore, the Pentecostals in Zimbabwe believe in the gifts of the Spirit. According to Busenitz (2006) the gifts of the Spirit are supernatural abilities given to believers by God. In line with this thought, Lowe (2010) pointed out that these gifts demonstrate the power of God and are used for particular purposes such as prophesying and healing of the sick.

From this discussion, it can be noted that the gifts of the Holy Spirit, such as healing power, prophesying, speaking in tongues, the interpretation of tongues and the gift of deliverance, provide a basis for the key strength of Pentecostalism in Zimbabwe. The adherence to the Bible and the importance of accepting Jesus Christ as personal Lord and Saviour, distinguish Pentecostal churches in Zimbabwe from other churches. The emphasis on the baptism of the Holy Spirit that enables Christians to live an empowered life also marks Pentecostalism in Zimbabwe.

\section{Methodology}

A qualitative approach was used for this study. Data were collected through interviews and participant observation. Sixteen participants were interviewed, using purposeful sampling. According to Michael (2005), purposeful sampling is a technique in which the researcher uses his/her own judgment to choose the population. Four ordained female pastors from the AFM were interviewed about challenges that they have faced as female leaders; four overseers in ZAOGA FIF were interviewed to gain a clear understanding of the ethics of leadership; eight members were interviewed, two from UFI, two from Heartfelt International Ministries, two from the Full Gospel Church of God and two from Faith Ministries. Apart from the interviews, participant observation was used. The researcher attended five gatherings: three from ZAOGA FIF; one from the AFM; and one from Heartfelt Ministries. Such gatherings helped the researcher to see how women are portrayed, engaged and function in the presence of male counterparts. Moreover, the researcher also used her experience, since she is a female pastor. In addition, secondary data, such as books and journals were also used. Hence, as much information as was possible was gathered.

\section{Data Analysis}

Out of the 16 interviewees, four reflected that a major barrier to the leadership of women is the misinterpretation of scriptures. In support of this, Brekus (2014) points out that Paul instructs, "as in all congregations of saints, women should remain silent in churches. They are not allowed to speak, but must be in submission, as the law says, if they want to inquire about something, they should ask their own husbands at home, for it is disgraceful for a woman to speak in the church" (1 Corinthians 14:33-35). Paul also 
instructs, "Now I want you to realize that the head of every man is Christ, and the head of the woman is the man ..." (1 Corinthians 1:13). Therefore, it can be noted that these scriptures, if taken at face value, discriminate against female leadership in the church.

However, if the interpretation of scriptures is done correctly, it shows that God's use of women should stretch to having them in executive positions. Heroines of biblical times like Esther, Naomi and Deborah, show traits of tenacity, thereby showing that they occupied a significant space as propounded by Paul, where he says "there is neither male nor female, Greek nor Jew." This implied gender balance, which should then naturally be followed in Zimbabwe Pentecostal churches.

Apart from the interviewees' views, the researcher (in person as well as through empirical research) has experienced marginalisation through oppressive interpretative practices of the Bible. Although the researcher has been given some voice as a pastor because of the belief that says the Holy Spirit communicates with both men and women, that same voice is taken away when female pastors are subordinated to male pastors. Hence, even though female leaders are not completely silenced, they are treated as subordinate to male leaders. This shows elements of gender discrimination in the Zimbabwean Pentecostals.

In addition to the above, three interviewees expressed the view that women are enemies of themselves. In support of this view, Biri $(2012,41)$ points out that sometimes women are their "own worst enemies." He further argues that women gossip against each other and do not vote for a fellow woman. The AFM uses ballots when selecting their leaders, but the researcher has observed that if there are women nominated to compete in the election, both men and women nominate men, thus showing that women have no confidence in each other and they cannot trust each other. This is the reason why women are few in leadership positions. In this instance, it implies that it is not a matter of discriminating against women but of attitude towards each other as women. This explains why, when a woman stands up preaching, such statements come out "handisi mukadzi kana ndamira pano nditori murume chaiye." "I am not a woman when I stand here, I am a real man." This will be said trying to seek approval in showing that they can perform to the standards of men. At the same time, from experience, the researcher has learnt that it seems if women are to rise to prominent leadership positions, they should prove that they can perform according to the standards set for men. Thus, there is a need to rethink the methods used to curb gender discrimination in Pentecostal churches.

Three interviewees argued that the way God is portrayed in the Bible is also a pointer to gender discrimination. In the same line of thought, Elaine (2013) points out that language such as father, king, lord, bridegroom and husband portray God as a male figure. Elaine further argues that even actors and authors depict God as male. In support of this, Billy Graham's Evangelistic Association (2004) also argues that God consistently describes himself in the masculine gender, presenting Him with an 
emphasis on masculine qualities of fatherhood, protection, direction and strength. Moreover, God, even in the incarnation, chose to present himself as a man. Thus, feminists such as Elaine (2013) argue that this masculine presentation of God has become a source of the marginalisation of women. However, if one goes back to the original meaning of the personal name of God, which is Yahweh according to Exodus 3, "Yah" is feminine and "weh" is masculine. Hence, in light of this, the name Yahweh is a combination of both female and male.

Also, two interviewees pointed out that women are not available either for secular work or church business due to house chores and responsibilities, thus affecting their leadership roles. In support of this, Siobhan (2000) also suggests that women have a number of excuses for not reporting for duty, for example, either they are not feeling well due to pregnancy, or their baby will not be well. Hence, too many family commitments affect the availability of women for their leadership roles. However, although this may sound true, if these reasons are closely looked at, one may conclude that these are beyond anyone's control. Thus, the argument does not hold much water in discriminating against women for any leadership role.

Furthermore, out of the 16 interviewees, one pointed out that the passivity of women is also considered as a contributing factor to their marginalisation. In support of this, Phiri (2012) argues that women lack leadership skills, capacity and exposure. However, there is a need for balanced teachings so that women, whether in the secular or church sphere, can receive an opportunity for training and empowerment. Capacity development thus becomes a necessity for women.

Two interviewees argued that men feel threatened by women's leadership capacity, so they would rather oppress them. The researcher has experienced such opposition when men were against her in rising to the position of a senior pastor. Had it not been for the grace of God, the researcher would not have been holding such a post. The insecurity of men forces them to block women from taking leadership positions, thereby reinforcing gender discrimination in the church.

Two interviewees argued that the influence of a patriarchal society contributes to gender imbalances, even in the church. In the same line of thought, Chitando (2013) points out that socio-cultural factors affect the empowerment of women because of a patriarchal society. He further highlights that Zimbabwe is a patriarchal society and that it is engraved in the system of the church. Thus, cultural barriers impede the rising of women to top leadership. History, therefore, shows that culturally it was better to educate a boy child rather than a girl child, causing women to grow up thinking that they are inferior to men.

From the discussion above, it can be noted that there are biblical and secular arguments that have contributed to the discrimination of women. However, one cannot only ask why this problem exists, instead one should ask why and how this problem has been 
allowed to become ingrained over time. Hence, there is a need to rethink the methods that have been employed in the Pentecostal churches to curb gender discrimination. Rethinking would, therefore, give women an opportunity to showcase their leadership skills and prove that they are capable of leadership.

\section{Current Methods Used to Curb Gender Discrimination in Selected Pentecostal Churches}

\section{Ordination of Women}

Two interviewees from the AFM and two from Heartfelt Ministries acknowledged that Pentecostal churches had used a number of methods to curb gender discrimination in their churches. They pointed out that one of the methods, that have been used in church leadership in Zimbabwe, is the ordination of women. The history of the Pentecostals in Zimbabwe shows that bias against women was prevalent (Kwaramba 2018). Women were considered as helpers in the ministry, just as they were women in Jesus' ministry (Luke 8:1-3, NIV). A number of reasons, as outlined above, were given for not accepting the leadership role of women in churches. However, the Pentecostals in Zimbabwe have attempted to break that stained-glass ceiling. Kwaramba (2018) points out that women and men in the AFM in Zimbabwe have been actively campaigning with the slogan: "More women in top positions in the AFM in Zimbabwe." Most Pentecostals such as the ZAOGA FIF, Heartfelt Ministries and the Full Gospel of God are now ordaining women as pastors. However, the ordination of women was considered "a trial" (Kwaramba 2018). This explains why the ordination of women is taking place at a slow rate, resulting in only a few women serving in leadership positions, although the majority of church members are women. In ZAOGA FIF, although many women are ordained, very few participate in the decision-making bodies. The management board and the day-to-day board is even divided into two, with the main one made up of men and a few women. According to Kwaramba (2018), the voice of a woman at the senior level of leadership in the AFM is not strong. It takes a great deal of courage and a clear sense of calling for women to make it to the table where key organisational and developmental decisions are made. Hence, these traits of discrimination show the need for rethinking the methods used to curb gender discrimination.

\section{Constitution}

In addition to the ordination of women, three interviewees from ZAOGA and one from the AFM noted that most Pentecostals in Zimbabwe have gone to the extent of including articles in their constitution in an attempt to curb gender imbalance. In support of this, Elaine (2013) points out that some churches have included articles in their constitutions that relate specifically to promoting and respecting equal rights for women and men and achieving gender balance in nominations for positions at different levels of the church. However, titles like bishop, apostle and president are reserved mainly for men. From empirical research it is clear that women are called administrators rather than the president of the church. Moreover, few women are appointed as archbishops. This 
article contends that it is imperative to rethink the methods that have been used and begin to apply what is written on paper. What is in the constitution should not be used to blind the people, instead it should be implemented with gender balance in mind. In the case of the AFM in Zimbabwe, it has in effect excluded echelons of its leadership structures for women by using gender exclusive language in its constitution (Kwaramba 2018). The AFM constitution 9.3.2 p. 25 says: "He must have a Diploma in Theology and qualify according to 1 Timothy ..." The constitution goes on to say: "He shall serve in the office as long as he is elected" (AFM constitution 9.3.3 p. 25). Thus, gender matters arise through this exclusive language.

\section{Commissioning of Women}

In addition to the above, out of the 16, five interviewees noted that the commissioning of women in other ministries such as deacons, elders, missionaries and evangelists had been used by most Pentecostals in Zimbabwe to curb gender discrimination. The Pentecostals in Zimbabwe today are of the notion that all positions are open to women. In theory, although all positions are open to women, sometimes the cultural morals and structural impediments prevent women from accessing certain positions (Elaine 2013). According to the AFM in Zimbabwe's constitution 15:3.1, the elders (who may be male or female) may preach and conduct services, baptise believers, lay hands on and pray for the sick, bury the dead, consecrate children when authorised by the pastor or administer the Lord's Supper. However, Kwaramba (2018) points out that when it comes to the leadership of women as deaconesses or elders, they seem to be guided by the pastor rather than by the Holy Spirit. The researcher has observed that of the entire leadership at a church, the majority will be men. Thus, this paper emphasises the need to rethink the methods used to curb gender discrimination in church leadership.

\section{Enrolment of Women in Theological Training Centres}

In addition to the methods above, three interviewees stated that enrolment of women in theological training centres had been used in Pentecostals in Zimbabwe as a way to curb gender imbalance in church leadership. The quota system has been introduced. However, Kwaramba (2018) notes that the number of men studying theology is three times as high as the number of women pursuing the same studies. The quota system is not even implemented. He further says that the "voters" at the college of the AFM in Zimbabwe include women voters and the college is "not allowed" to vote for them. In support of this view, Durham (2016), states that resistance to women in ministry in Pentecostals is increasing, even as a significant number of academic and performance awards are conferred on female Bible students. He further says that despite a gift and passion for ministry, female students are among the last in their class to receive offers to lead congregations, and instead, many settle for serving as lay leaders. In ZAOGA FIF, despite the women's achievements in Bible school and evidence of how gifted they are, they are less likely to be appointed for a senior pastoral position, but more likely to be appointed as associate pastors; moreover, earning lower salaries with fewer benefits than their male counterparts. The researcher's salary as a pastor is far below the salary 
of her male counterparts, despite the fact that she attended college for the same number of years and holds the same positions. Gender bias is the main reason that has slowed down the advancement of female leaders, even though there are women who are gifted and have equal capacity for being a leader.

It can, therefore, be noted that although policies provide a framework to promote gender balance, the tide of gender discrimination is still evident. Although there are a number of methods that have been employed to curb gender discrimination, a number of discrepancies still exist, hence the need to rethink methods to ensure gender balance. Thus, women in Pentecostal churches in Zimbabwe can see top leadership positions, but to them, they are unreachable.

\section{Recommendations}

Quite often, when people give a "nod" to female leaders but do nothing to effect change, there is a need to move beyond just rendering a "nod" to women in ministry; instead, it is high time to prioritise the inclusion of women in church leadership and begin to change the mindset, so that gender discrimination is dealt with once and for all. There is a need to provide role models in church leadership to curb gender discrimination. Stories of successful women leaders, such as Plaatjies-Van Huffel, should be shared. This will open the eyes of the people to begin to see that women leaders are the norm, and not anomalies. It is imperative for everyone to be intentional about the acceptance of women in leadership.

Pentecostals in Zimbabwe should have a responsibility to intentionally educate their followers that it is biblically sound for women to take up leading positions. It is, therefore, important for members to be taught how to navigate controversial scriptures about women in church leadership. Rethinking Pauline's prohibition of women becomes imperative. 1 Tim 2:11-15 should be understood in the historical context where Paul addressed the issue of order in worship.

Moreover, to curb gender discrimination, Pentecostal churches in Zimbabwe are advised to implement change incrementally. The language of the preacher, church materials or books should not be gender biased. There is a need to implement changes in church policies regarding women. These small changes will help the church to adjust to the cultural shifts and embrace the changes. In support of this, Dr Mel Ming, quoted by McKnight (2016), says: "If you want to change culture, if you can help them experience change in a non-threatening way, they are more likely to embrace it than if you polarize it. Allow them to taste the new without even knowing they are." Hence, since gender balance cannot happen overnight, people must be strategic and intentional in their attentiveness to gender parity in the leadership of the church. According to Elaine (2013), strategies and priorities are the agreed common tools to be used as markers in the process of developing gender justice in the church. Elaine further points out that these ensure that measures are intentionally built into programmes and structural 
arrangements. Hence, policies will provide a framework in which inclusiveness is implemented.

The biblical narrative is another tool that can be used to lead people toward paradigm shifts. The message of inclusion and balance between men and women in the Bible need not be ignored, instead it should be implemented in the day-to-day life of Pentecostals. Hence, using biblical narratives as a replica for the culture of the church can become an effective way of curbing gender discrimination in Pentecostals in Zimbabwe.

Apart from using biblical narratives, Pentecostal churches in Zimbabwe should create new traditions and practices. By creating a structure for change, women become an integral part of the leadership. Robert Kegan, quoted by McKnight (2016), argues that most people need a structure to help them channel their aspiration, and to test and gain distance from their big assumptions, to steadily build a new set of ways to bridge the gap between intentions and behaviour. Pentecostal churches in Zimbabwe, therefore, need to include women representation in church policies; and this should be done with gender balance in mind.

Another method proposed to curb gender discrimination is to rethink election. It is good for members in the Pentecostals in Zimbabwe to vote for leaders as a way of promoting democracy. However, the challenge lies in the trend of voting the same people into office over and over again - and this trend must be changed. Voting for a woman in the position of president in Pentecostals in Zimbabwe should be deliberately carried out, otherwise it will take years before women appear in the higher echelons of leadership structures.

Women also need to be paid equally for their services in the church, just like their male counterparts. Payment for services reflects the value women bring to the table. Just as Jesus did not make a distinction between male and female, female pastors in Pentecostals in Zimbabwe ought to receive equal pay to men. In fact, Jesus even revered women more, since he never rebuked them. It becomes discriminative to pay women less money. "Haven't you read?" he replied, "that at the beginning the Creator made them male and female" (Mathew 19:4); thus, for Christ, women have an intrinsic value equal to that of men. Women are created in the image of God, just as men are. According to John 8:10-11, Jesus spoke freely with the woman guilty of adultery without rebuking her.

It is noted that apart from women being helped to the top positions, they have the ability to make a difference, rising above discrimination towards their own freedom. McKnight (2016) says that oppression does not lie in the eye of the beholder; it tugs at the soul of the one who feels it. Therefore, women, since they know the pain of being oppressed, should participate in their own emancipation. 


\section{Conclusion}

From the discussion above, it can be concluded that the patriarchal challenge that has led to the lack of female leadership in Zimbabwean Pentecostals was perpetuated by traditional cultural and theological views. However, strategies and policies have been the common methods employed in the Pentecostal churches in Zimbabwe to curb gender discrimination. The ordination and the commissioning of women in other ministries have become methods which the Pentecostals in Zimbabwe have used to curb gender imbalance. However, there are anomalies. Although women can now be pastors, they cannot rise through the church's positions to become either Overseer or President, unless they are married. Exclusive male language is used in the constitution. For example, "He must have a diploma in theology and qualify according to 1 Timothy" (AFM Constitution 9.3,2). Thus, the exclusive male language contributes to gender discrimination.

In theory, all positions are open for women. However, sometimes the cultural mores and structural impediments prevent women from climbing up the ladder. Therefore, Pentecostals in Zimbabwe would not simply want to follow the traditional culture, rather they would want to rethink the methods to curb gender discrimination in order to come up with an innovative, non-patriarchal theology. Rethinking the methods to curb gender discrimination would contribute to the building of a new, bright future with gender balance. Thus, change cannot be achieved by appointing only one or two women to a leadership position. If Pentecostals in Zimbabwe are serious about curbing gender discrimination, they should rather build itineraries, roadmaps and paths of transformation so that a cultural change is noted.

\section{References}

Amanze, J. 2015. “Glossolalia: Divine Speech or Man-made Language. A Psychological Analysis of the Gift of Speaking in Tongues in the Pentecostal Churches in Botswana." Studia Historiae Ecclesiasticae 41 (1): 3-19. https://doi.org/10.25159/2412-4265/84.

Anderson, P. 2012. Re-visioning Gender in Philosophy of Religion: Reason, Love and Epistemic Locatedness. Burlington, VT: Ashgate Publishing.

Bhatasara, S. 2017. "Pentecostals and the Body." Annual Review of the Sociology of Religion, vol. 8 .

Biri, K. 2012. "The Silent Echoing Voice: Aspects of Zimbabwean Pentecostalism and the Quest for Power, Healing and Miracles.” Studia Historiae Ecclesiasticae 38: 37-55.

Brekus, C. 2014. “The Controversy over Women's Religious Leadership in the United States of America". Phikappa Phi Forum 94 (1): 4-6.

Busenitz, N. 2006. "The Gift of Tongues: Comparing the Church Fathers with Contemporary Pentecostalism." The Master's Seminary Journal 1 (1): 61-78. 
Chitando, E. 2013. Prophets and the Bible in Zimbabwe. Bamberg: University of Bamberg Press, 95-112.

Durham, L. 2016. "The Debate over Female Leadership in Ministry." Annual Contemporary Issues in Transformative and Innovative (CITI) Leadership Conference, 2.

Elaine, N. 2013. "Identifying and Dismantling Patriarchy and other Systems of Oppression of Women.” International Review of Mission World Council of Churches, 23.

Gabaitse, Rosinah M. 2015. "Pentecostal Hermeneutics and the Marginalization of Women." Scriptura 114: 1-12. https://doi.org/10.7833/114-0-1043.

Guti, J. 2012. "Pentecostalism and Exclusion of Women in Positions of Leadership: A Case of Pentecostal Churches in Harare Zimbabwe.” Master's dissertation, University of Fort Hare, Alice, Eastern Cape, South Africa. www.vitalseals.ac.za.

Jantzen, G. 1999. Becoming Divine: Towards a Feminist Philosophy of Religion, Blooming, IN: Indiana University Press.

Kgatle, M. 2019. Spirit Baptism and the Doctrine of Initial Evidence in African Pentecostal Christianity: A Critical Analysis. AOSIS. https://doi.org/10.4102/hts.v76i1.5796.

Kwaramba, J. 2018. “A Practical Theological Perspective on Female Leadership in a Pentecostal Context in Zimbabwe." Doctoral thesis, University of Pretoria, South Africa. www.books.google.co.zw.

Laden, G. 2012. "How many Countries have had a Woman Leader?” (blog post). August 12. https://scienceblogs.com/gregladen/2012/06/03/how-many-countries-have-ever-had-awoman-leader.

Lowe, M. 2010. "Breaking the Stained-glass Ceiling: Collaborative Leadership Theory as a Model for Women in Theological Higher Education." Journal of Women in Educational Leadership. University of Nebraska, Lincoln.

Machingura, F. 2011. "The Significance of Glossolalia in the Apostolic Faith Mission Zimbabwe." Studies in World Christianity, vol. 17, no. 1. https://doi.org/10.3366/swc.2011.0003.

Machingura, F. 2018. Pentecostalism and Human Rights in Contemporary Harare, Zimbabwe. Cambridge Scholars Publishing.

Mapuranga, T. 2013. "Bargaining with Patriarchy? Women Pentecostal Leaders in Zimbabwe." Fieldwork in Religion 8 (1): 74-91. https://doi.org/10.1558/firn.v8i1.74.

McKnight, S. 2016 “Ten Ways to Promote Women in your Church.” Lecture, Assemblies of God Theological Seminary, Springfields. 
Michael, P. 2005. Qualitative Research. www.onlinelibrary.wiley.com.

Msafropolitan, H. 2012. African Feminist. Hoboken, New Jersey: Wiley Blackwell.

Nadar, S. 2004. “On Being a Pentecostal Church: Pentecostal Women's Voices and Vision." The Ecumenical Review, vol. 53, no. 3.

Phiri, I. 2012. "The Church and Women in Africa." In The Church and Women in Africa, edited by E. K. Bongma. Hoboken, New Jersey: Wiley Blackwell. https://doi.org/10.1002/9781118255513.ch17.

Plaatjies-Van-Huffel, Mary-Anne E. 2019. “A History of Gender Insensitivity in URCSA.” Studia Historiae Ecclesiaticae 45 (3). https://doi.org/10.25159/2412-4265/6250.

Rutoro, E. 2012. An Analysis of the Impact of Socio-Cultural Factors on the Effective Implementation of Gender Sensitive Policies in Education Management.” Doctoral thesis, Zimbabwe Open University, Harare, Zimbabwe. www.zou.ac.zw.

Sande, N. 2016. "Faith and Equality: Rethinking Women in Leadership Positions in Pentecostalism." Journal of Gender and Religion in Africa, vol. 22, no. 2.

Siobhan, A. 2000. Family Responsibilities and Women's Working Lives. Curtin University of Technology Discussion paper series 00/3/.

Togarasei, L. 2010. Churches for the Rich? Pentecostalism and Elitism. Uppsala: Swedish Science Press.

Togarasei, L. 2016. "Historicising Pentecostal Christianity in Zimbabwe." Studia Historiae Ecclesiaticae, vol 42, no. 1. 